Жемчужна Ганна Олександрівна, магістр психології, ПрАТ «ВНЗ «МАУП», 02000, вул. Фрометівська, 2, м. Київ, Україна; zhemchuzhnaya1981@ukr.net, +38 (097) 889-69-69

ORCID: https://orcid.org/0000-0001-5755-0757

\title{
ПСИХОДІАГНОСТИЧНЕ ДОСЛІДЖЕННЯ ПРОБЛЕМИ СПІВЗАЛЕЖНОСТІ В ПОДРУЖНІХ (ПАРТНЕРСЬКИХ) ВІДНОСИНАХ
}

\begin{abstract}
Анотація
Ключові слова: співзалежність, партнерські (подружні) стосунки, психодіагностика.

Постановка проблеми. Міжособистісна співзалежність негативно впливає на усі аспекти життя людини. В основі даної проблематики лежить недостатня диференціація «образу Я», адже співзалежні особи не мають чітких уявлень про власні бажання, потреби і почуття, тому можливість адекватного їх вираження і реалізації в парі ускладнені.

Аналіз останніх досліджень і публікацій. Проблема залежностей $є$ однією з найбільш актуальних в сучасному суспільстві. Фахівці в області залежностей найчастіше розглядають співзалежність як сімейну проблему. Аналіз психологічної літератури 3 проблеми дозволяє розуміти співзалежність не тільки як вторинне явище, пов'язане з алкогольною та наркотичною залежністю близької людини, а як порушення розвитку особистості, що формується в ранніх дитячо-батьківських відносинах. Аналіз наукової літератури 3 питань сутності та природи залежності свідчить про глибоку теоретичну і емпіричну розробленість феномена залежності (адикції) і наявності добре сформованого термінологічного апарату для його вивчення.
\end{abstract}


Високий ризик поширення традиційних і нових видів адикції актуалізує проблему вироблення раціональних стереотипів психогігієнічної поведінки у реальних і потенційних аддиктів. Найбільшу актуальність зберігає проблема вивчення залежності як негативного біопсіхосоціодуховного явища i розробки способів, здатних не тільки стримати зростання, але і надати ефективну протидію виникненню і подальшому поширенню цього синдрому.

Формулювання мети статті. Мета полягає у вивченні психологічних особливостей особистості в співзалежних стосунках у парі.

Виклад основного матеріалу. Психологічна база досліджування склала 82 осіб (41 пара ), контрольна досліджувана група - 40 осіб (20 подружніх пар) - які характеризувалися стабільними, сприятливими взаєминами адаптовані пари, що не мають подружніх утруднень і задоволені шлюбом; основна досліджувана група - 42 осіб (21 подружні пари ) - які зверталися до психологічної консультації у зв'язку 3 проблемами співзалежності, незадоволення шлюбом,- це ті пари, які можуть бути віднесені до пізніх, або фінальних, етапів залежності. Для дослідження психоемоційних станів досліджуваних основної та контрольної груп були обрані валідні психодіагностичні методики: Тест-опитувальник СпілбергераХаніна (діагностика тривожності); Опитувальник тріади любові по Стернбергу; Тест на співзалежність Фішера; Тест «впевненість у собі» Райдаса ; Виявлення любовної залежності (по Єгорову). В проведеному дослідженні були виявлені стратегії міжособистісної взаємодії жінок і чоловіків зі співзалежною поведінкою.

Висновки та перспективи подальших досліджень. Більшість жінок та чоловіків, які взяли участь у нашому дослідженні, не намагаються приховувати звичайні страхи, занепокоєння або свою невпевненість. Вони намагаються добре виглядати в своїх очах та в очах партнерів, не завжди потребують бути «правими», відчувають нестачу довіри з боку близької людини і занепокоєння при встановленні близьких, довірливих відносин. Результати наших досліджень підтверджують дані джерел наукової 
літератури, що співзалежним людям властиво: заперечення, страх, тривога, сором, вина, перфекціонізм, нав'язливі думки, невміння дотримуватися кордону особистості, схильність до маніпулювання, ригідність.

Дослідження проблеми співзалежності є значущими для психологів, тому питання потребує більш грунтовного теоретичного вивчення.

\section{Аннотация}

Жемчужная А. А., магистр психологии, ЧАО «ВУЗ «МАУП», г.Киев, Украина. Психодиагностическое исследование проблемы созависимости в семейных (партнерських) взаимоотношениях.

Ключевые слова: созависимость, партнерские (супружеские) отношения, психодиагностика.

Постановка проблемы. Межличностная созависимость негативно влияет на все аспекты жизни человека. В основе данной проблематики лежит недостаточная дифференциация «образа Я», ведь созависимые лица не имеют четких представлений о собственных желаниях, потребности и чувства, поэтому возможность адекватного выражения и реализации в паре затруднены.

Анализ последних исследований и публикаций. Проблема зависимостей является одной из наиболее актуальных в современном обществе. Специалисты в области зависимостей чаще всего рассматривают созависимость как семейную проблему. Анализ психологической литературы по проблеме позволяет понимать созависимость не только как вторичное явление, связанное с алкогольной и наркотической зависимостью близкого человека, а как нарушение развития личности, формируется в ранних детскородительских отношениях. Анализ научной литературы по вопросам сущности и природы зависимости свидетельствует о глубокой теоретической и эмпирической разработанность феномена зависимости (аддикции) и наличии хорошо сформированного терминологического аппарата для его изучения. Высокий риск распространения традиционных и новых видов 
аддикции актуализирует проблему выработки рациональных стереотипов психогигиенической поведения в реальных и потенциальных аддиктами. Наибольшую актуальность сохраняет проблема изучения зависимости как негативного биопсихосоциодуховного явления и разработки способов, способных не только сдержать рост, но и предоставить эффективное противодействие возникновению и дальнейшему распространению этого синдрома.

Формулировка цели статьи. Цель заключается в изучении психологических особенностей личности в созависимых отношениях в паре.

Изложение основного материала. Психологическая база исследования составила 82 человек (41 пар), контрольная исследуемая группа - 40 человек (20 супружеских пар) - которые характеризовались стабильными, благоприятными отношениями, адаптированностью, отсутствием супружеских затруднений и удовлетворенностью браком; основная исследуемая группа - 42 человек (21 супружеские пары) - которые обращались за психологической консультацией в связи с проблемами созависимости, недовольством браком, - это те пары, которые могут быть отнесены к поздним, или финальным, этапам зависимости. Для исследования психоэмоциональных состояний исследуемых основной и контрольной групп были выбраны валидные психодиагностические методики: Тест-опросник Спилбергера-Ханина (диагностика тревожности) Опросник триады любви по Стернбергу; Тест на созависимость Фишера; Тест «уверенность в себе» Райдаса; Выявление любовной зависимости (по Егорову). В проведенном исследовании были выявлены стратегии межличностного взаимодействия женщин и мужчин с созависимым поведением.

Выводы и перспективы дальнейших исследований. Большинство женщин и мужчин, принявших участие в нашем исследовании, не пытаются скрывать обычные страхи, беспокойства или свою неуверенность. Они стараются хорошо выглядеть в своих глазах и в глазах партнеров, не всегда требуют быть «правыми», испытывают недостаток доверия со стороны 
близкого человека и беспокойства при установлении близких, доверительных отношений. Результаты наших исследований подтверждают данные источников научной литературы, созависимым людям свойственно: отрицание, страх, тревога, стыд, вина, перфекционизм, навязчивые мысли, неумение соблюдать границы личности, склонность к манипулированию, ригидность. Исследование проблемы созависимости явлется значимым для психологов и требует более основательного теоретического изучения.

\section{Annotation}

Zhemchuzhna G. O., Magister of Psychology, The Private Joint-Stock Company Higher Educational Institution Interregional Academy of Personnel Management; Kyiv, Ukraine. Psychodiagnostic study of the problem of coexistence in family (partner) relationships.

Key words: interdependence, partnership (marital) relations, psychodiagnostic.

Formulation of the problem. Interpersonal interdependence negatively affects all aspects of human life. At the heart of this problem is the lack of differentiation of the "image of me", because the co-dependent persons do not have clear ideas about their own desires, needs and feelings, therefore the opportunity to adequately express and implement them in a couple is complicated. Analysis of recent research and publications. The problem of dependencies is one of the most urgent in modern society. Specialists in the field of dependencies often consider coexistence as a family problem. The analysis of psychological literature on the problem allows us to understand the co-dependence not only as a secondary phenomenon associated with the alcohol and drug addiction of a loved one, but as a violation of the development of personality, which is formed in early child-parent relationships. Analysis of scientific literature on the nature and nature of dependence shows a profound theoretical and empirical development of the phenomenon of dependence (addiction) and the presence of well-formed terminology apparatus for its study. The high risk of spreading traditional and new 
types of addiction actualizes the problem of developing rational stereotypes of psycho-hygienic behavior in real and potential addicts. The greatest urgency remains the problem of studying the dependence of both the negative biopsy and the spiritual phenomenon and the development of methods that can not only restrain growth, but also provide effective counteraction to the onset and further spread of this syndrome.

Formulating the purpose of the article. The aim is to study the psychological characteristics of a person in co-dependent relationships in a couple.

Presenting main material. The psychological research base was 82 persons (41 couples), the control group under study - 40 (20 couples) - characterized by stable, favorable relationships, adapted couples who have no marital problems and are satisfied with marriage; The main study group - 42 (21 married couples) - who turned to psychological counseling in connection with problems of coexistence, dissatisfaction with marriage - these are the pairs that can be attributed to the late or final stages of dependence. For studying the psycho-emotional states of the studied main and control groups, valid psychodiagnostic techniques were selected: Spielberger-Khanin test questionnaire (diagnosis of anxiety); Questionnaire of Triad of Love by Sternberg; Fischer coexistence test; Raidass self-confidence test; Detection of love affiliation (according to Egorov). In the study, strategies for interpersonal interaction between women and men with co-dependent behavior were identified.

Conclusions and perspectives of further research. Most of the women and men who participated in our study do not try to conceal their usual fears, anxieties, or their uncertainty. They try to look good in their eyes and in the eyes of their partners, they do not always need to be "right", they lack the trust of a loved one and worry when establishing close, trusting relationships. The results of our research confirm the data of the sources of scientific literature that is characteristic of co-dependent people: negation, fear, anxiety, shame, fault, perfectionism, obsessive thoughts, inability to adhere to the boundary of personality, propensity to 
manipulation, rigidity. Studies of the problem of coexistence are important for psychologists, so this question requires a more thorough theoretical study.

Ключові слова: співзалежність, партнерські (подружні) стосунки, психодіагностика.

Постановка проблеми. Актуальною проблемою сьогодення $\epsilon$ різноманітні залежності, перед небезпекою яких стоїть людина. Співзалежні відносини аналогічні будь-яким іншим залежностям. Останнім часом залежність (аддикція) є предметом розгляду великої кількості дисциплін (медицини, соціології, психології та ін.). За даними різних авторів (В. Д. Менделевич, Б. Уайнхолд и Дж. Уайнхолд, Е. В. Смельянова), існує понад 150 різновидів залежності. До цієї категорії належать як традиційні хімічні форми залежності (наркоманія, алкоголізм, тютюнопаління та ін.), так й зовсім нові - гемблінг (залежність від азартних ігор), інтернет-адикції та ін. Серед них міжособистісна співзалежність частіше виглядає незначною за своєю поширеністю та наслідками. Між тим, співзалежність стосується не тільки міжособистісної сфери, але й особистості, негативно впливаючи на усі аспекти життя людини (В. І. Литвиненко, О. Ф. Кернберг, О. А. Шорохова). Як вказують Н. Г Гаранян та А. Б. Холмогорова, співзалежні відносини перетворюються на «трагедію цілого життя», коли нічого не збудовано, але багато чого поруйновано - душевне та фізичне здоров'я, можливості інших відносин визначити суть міжособистісних конфліктів у парі під іншим кутом зору. Причиною розвитку дисфункціональних стосунків виявилося явище, назване «співзалежністю». В зв'язку з широкою поширеністю цього явища, важливість грунтовного дослідження різних аспектів даної проблеми цілком очевидна. В основі даної проблематики лежить недостатня диференціація «образу Я», адже співзалежні особи не мають чітких уявлень про власні бажання, потреби і почуття, тому можливість адекватного їх вираження i реалізації в парі ускладнені. Такі стосунки передбачають розчинення меж 
власної особистості, тоді як нормальні стосунки - це коли партнер має якусь спільну сферу 3 іншим і окрему частину особистого життя, про яку інший знає i не намагається контролювати, довіряє. На основі первинної спів залежності, відбувається формування всіх інших видів залежностей i розвиток вторинної співалежності. Вторинна співзалежність є складним патологічними станом, сформованим у родичів пацієнтів, які страждають хімічними і не хімічними видами залежностей, що визначає порушення психічного здоров’я i особистісного розвитку, що виявляється на ментальному, емоційному, соціальному, духовному рівнях, що включає в себе порушення поведінки i соціальної адаптації. Залежність особи, 3 психологічної точки зору, являє собою неконтрольований контакт особи 3 певною хімічною речовиною або процесом, який змінює стан іiі свідомості, штучним чином повертаючи їй відчуття психологічного комфорту. При цьому неконтрольованість контактів призводить до появи великої кількості проблем уповсякденному житті людини, призводить до погіршення іiі життя як у матеріальному, так i в духовному планах, i зрештою загрожує деградацією особистості. Достатньо велика поширеність подібних явищ спонукає науковців шукати глибинні причини їх виникнення, щоб запобігти подальшому їх розвиткові і поширенню. Тому актуальним $\epsilon$ висвітлення взаємозв’язку залежностей особистості з їі співзалежністю від стосунків.

Аналіз останніх досліджень і публікацій. Проблема залежностей $\epsilon$ однією 3 найбільш актуальних в сучасному суспільстві. Фахівці в області залежностей найчастіше розглядають співзалежність як сімейну проблему (М. Бітті, 1997; R. Т. Potter-Effron, 2002; Д. А. Цірінг 2009; Н. Курек, 2004; В. Москаленко, 2006; Е. Назаров, 2000; Н. Манухина 2009, Р. Хемфелт 3 співавт., 2007; Д. Бредшоу, 1989, Б. і Д. Уайнхолд, 2011 і ін.). Аналіз психологічної літератури з проблеми дозволяє розуміти співзалежність не тільки як вторинне явище, пов'язане 3 алкогольною та наркотичною залежністю близької людини, а як порушення розвитку особистості, що формується в ранніх дитячо-батьківських відносинах. 
При описі синдрому залежності, вчені використовують кілька синонімів [8], які певною мірою відрізняються один від одного за змістом понять: пристрасть, залежність (адикція) і девіація. Найбільш багатозначним є поняття залежності. У перекладі з англійської (addiction) воно означає схильність, звичку. У медичну практику поняття введено в 1964 році комітетом експертів ВООЗ для застосування нарівні з термінами «хвороблива пристрасть», «звичка», «наркоманія», «алкоголізм». У визначенні ВООЗ [5] поняття «залежність» означає «стан періодичної або хронічної інтоксикації, що викликається повторним вживанням природної або синтетичної речовини». Тому спочатку термін застосовувався в його вузькому значенні і вживався виключно для опису лікарської, тютюнової, алкогольної та наркотичної залежностей. Вузьке розуміння терміна знайшло відображення і у визначенні М. Кордуелла [9], згідно з яким залежність означає такий різновид розладу особистості, при якій виникає потреба в підтримці інших людей або опорі на них у зв'язку 3 нездатністю прийняття індивідом найпростіших самостійних рішень при одночасному відчутті почуття неадекватності і безпорадності.

В широкому значенні «залежність» характеризує стан необхідності або потребу в чомусь або комусь для підтримки, функціонування чи виживання. Вона супроводжується появою наполегливого бажання, яке проявляється у відчутті гострої необхідності вчинення будь-якого вчинку або здійснення діяльності [25]. Люди, які відчувають пристрасть до чого-небудь або когонебудь, є аддиктами, що в перекладі з англійської означає «завзятий любитель», людина, яка захоплюється, фанат. Термін «аддикт» у науковій літературі застосовується для характеристики людей у двох значеннях [3]:

1) людей, нездатних припинити прийом різних препаратів;

2) людей, які витрачають на захоплення весь свій вільний час.

Д. Р. Меєрс [6, с. 164], визначаючи залежність як «наслідок збочення нормальності», вносить новий зміст у розуміння терміна, істотно розширюючи його інтерпретацію і зближуючи 3 поняттям девіації (лат. 
Deviatio - відхилення). Аналогічно сприймає аддикцію як форму патологічної поведінки, яка не відповідає нормі, і Л. М. Доддс [6, с. 164], що визначає їі як «активність, що спонукається компульсивно та характеризується інтенсивністю і неослабним завзяттям, відносною втратою автономії Его, включаючи здатність реагувати на фактори реальності і функції турботи про себе». Дане трактування поняття дозволило істотно розширити межі його застосування і використовувати по відношенню до різних видів нехімічної залежності, при якій об’єктом потягу став поведінковий патерн, а не хімічна речовина. Найкоротшу і майже недиференційовану за змістом дефініцію залежності, яка в даному форматі стає застосовною до більшої частини психічних і поведінкових розладів, дає A. W. Shaef, визначаючи іiі як «будьякий процес, над яким ми не владні» [4, с. 18]. Вчений вперше запропонував поряд з хімічними (субстанціональними) залежностями (алкоголь, наркотики, тютюн, їжа) виділяти нехімічні (поведінкові) залежності або залежності від процесу (накопичення грошей, азартні ігри, секс, робота, інтернет, релігія).

Проявом будь-якого виду залежності $є$ залежна поведінка. Під залежною (адиктивною) поведінкою В. Д. Менделевич [7, с. 344] розуміс «різновид девіантної поведінки, що характеризується непереборною підпорядкованістю власних інтересів інтересам іншої особи або групи, надмірною і тривалою фіксацією уваги на певних видах діяльності або предметах (фетишах), які стають надцінними, зниженням або порушенням здатності контролювати залученість в будь-яку діяльність, а також неможливістю бути самостійним і вільним у виборі поведінки». G. A. Marlatt, J. S. Baer, D. M. Donovan, D. R. Kivlahan [14, c. 230] визначають залежну (адиктивну) поведінку як «повторювану звичку, яка підвищує ризик захворювання і пов'язана з особистими i/або соціальними проблемами». На думку вчених, однією з головних характеристик адиктивної поведінки $є$ «втрата контролю». Її суть полягає в постійному відтворенні поведінкових патернів (повторюваність, рецидив), незважаючи на всі спроби перешкоджання цьому. При цьому спроби зміни адиктивної поведінки 
шляхом додаткових вольових зусиль або використання медикаментозних засобів часто закінчуються невдачею і поверненням до початкового стану.

Найбільш загальне уявлення про походження залежності обгрунтовано Ц. П. Короленком [11]. Вчений стверджує, що в основі залежності лежить закладений в самій природі людини потяг до задоволення, яке він отримує, задовольняючи як нижчі (фізіологічні), так і вищі (соціальні) потреби (в любові, соціальної приналежності, владі та ін.). Якщо потреби людини не задоволені раціональними способами, вона, відчуваючи себе нещасною i знедоленою, вдається до нераціональних способів задоволення, використовуючи хімічні та / або нехімічні засоби. Власне психологічне пояснення феномена залежності дає теорія залежної особистості, розроблена В.Д. Менделевичем [12]. Її суть полягає в існуванні загальних для всіх форм залежностей базових характеристик особистості, готової до підпорядкування, що шукає і знаходить в навколишньому світі «відповідний» об’єкт чи суб’єкт залежності. Розвитку особистої схильності до залежності сприяють такі особистісні характеристики індивіда: низький рівень самосвідомості; невпевненість в собі; переважання зникаючої мотивації; не сформованість функції прогнозу; екстернальний локус контролю та ін. Проте зв’язок залежної поведінки з наявністю рис залежної особистості досі залишається повністю не з'ясованим [12].

Таким чином, аналіз наукової літератури з питань сутності та природи залежності свідчить про глибоку теоретичну i емпіричну розробленість феномена залежності (адикціï) i наявності добре сформованого термінологічного апарату для його вивчення.

Особливість сучасного етапу розвитку суспільства полягає в постійному виникненні нових ризиків і небезпек, які сприяють неухильному збільшенню масштабів поширення залежності i, як наслідок, погіршення індивідуального і суспільного здоров'я. Високий ризик поширення традиційних i нових видів адикції актуалізує проблему вироблення 
раціональних стереотипів психогігієнічної поведінки у реальних і потенційних аддиктів.

В основі формування всіх видів залежностей лежать єдині фізіологічні механізми. Психологія мотивів залежності зводиться до 3 основних спонукань: отримання задоволення; подолання психо-емоційного стресу; збереження приналежності до певного індивіду і / або референтної групі.

Залежність, будучи досить дослідженою науковою категорією, залишається малодослідженою як соціальний i, особливо, духовний феномен. У визначенні сутності залежності досі переважає вузькомедична парадигма мислення - біомедичний детермінізм. Перехід до більш широкого погляду на залежність визначить зміну пріоритетів в підході до аналізу соціокультурних та морально-етичних умов і факторів їі формування та подолання.

Традиційно співзалежність в сім’ї розуміється як залежність ії членів від того члена сім’ї, який має потяг до наркотиків або алкоголю, і якого називають залежним. Однак це лише окремий випадок співзалежних відносин. У широкому сенсі слова, співзалежність - це емоційна залежність однієї людини від значимої для неї іншої людини. Співзалежність - одна 3 найпоширеніших проблем, що заважають повноцінному життю людей. Вона стосується не лише окремих особистостей, а й суспільства в цілому, яке створює умови, що сприяють співзалежним відносинам i їх передачі 3 покоління в покоління [13, с. 206]. Співзалежні люди відчувають постійну потребу в схваленні оточуючих, підтримують принижуючі гідність відносини і відчувають себе безсилими що-небудь змінити, не усвідомлюють своїх істинних бажань i потреб i не здатні переживати почуття справжньої близькості і любові [1]. «Співзалежність - це набутий розлад, що $\epsilon$ результатом зупинки (затримки) розвитку або пов'язаний 3 розвитком «прилипання», 3 якого можна згодом психологічно вирости» [12, с. 43]. «Співзалежність - патологічний стан, що характеризується глибоким поглинанням i сильною емоційною, соціальною або навіть фізичною залежністю від іншої людини. Найчастіше термін вживається по відношенню 
до родичів і близьких алкоголіків, наркоманів та інших людей з будь-якими залежностями, але далеко не обмежується ними» [2, с. 152]. Співзалежна людина, дозволивши поведінці іншої людини впливати на неї, стає повністю поглиненою тим, щоб контролювати дії цієї іншої людини, і таким чином регулювати власний стан.

Співзалежна людина перестає відрізняти власні потреби і цілі від цілей i потреб іншої. У неї немає власного розвитку: їі думки, почуття, вчинки, способи взаємодії і вирішення рухаються по замкнутому колу, циклічно i невідворотно повертаючи людину до повторення одних і тих же помилок, проблем і невдач.

Взаємовідносини, в яких один учасник співзалежний, а інший протизалежний, на жаль, не рідкісне явище [1]. Якщо людину виховували емоційно холодні батьки, то вона часто знаходить собі партнера, який буде більш залежний і прив'язаний. Людина, вихована залежними і прив'язаними батьками, буде шукати чоловіка більш незалежного. Подібна тяга до протилежностей є спробою вирішити не вирішені в ранньому дитинстві проблеми зв'язку та відділення. Але відносини «протилежностей» часто є більш конфліктними. Це конфлікт, як правило, є повторенням-програванням того конфлікту, який відбувався у подружжя в дитинстві з їх батьками або одним 3 них. Необхідно перетворювати його в можливості для зростання, а не розвивати як дисфункціональну поведінку.

Таким чином, залежна особистість не може побудувати здорові партнерські стосунки, що унеможливлює створення нею щасливої родини.

Патогенетичною основою співзалежності $\epsilon$ непродуктивні способи адаптації до відносин з патологічно зміненою особистістю. Соціальним механізмом, що підтримує співзалежність, є культивування жертовності, самовіддачі, безкорисливої допомоги ближньому. Елементи такої поведінки впроваджуються в школі, релігійній організації, а також засобами масової інформації. 
Роль жінки часто інтерпретується через служіння чоловіку і сім'ї, безмежну відданість і прихильність. При цьому продуктивні способи поведінки, засновані на силі особистості, ігноруються. Чим більше співзалежна людина втягується в роль рятівника, тим глибше стають іiі емоційні, поведінкові та особистісні деформації. Поступово вони об'єктивізуються - втрачають зв'язок із конкретною людиною, реалізуються у всіх сферах життя [1]. 3 іншого боку, чим значнішою стає вираженість співзалежності «рятівника», тим більше прогресує безініціативність «жертви» - втрачається необхідність проявляти самостійність і силу волі, боротися зі згубною звичкою. У співзалежних людей виявляються деструктивні уявлення про взаємини, емоційні та поведінкові розлади. На ментальному рівні домінують шаблонні переконання і установки: близьким потрібно допомагати, не можна кидати іншого в біді, слово може вилікувати, справжня любов все стерпить. Вони не відповідають реальності - не враховують патологічні механізми, які є основою алкогольної, наркотичної та інших залежностей. Відбувається підміна ефективної допомоги надмірним співчуттям, жалем, турботою, повсякденним відходом - ставленням, яке зручне хворому (залежному) і перешкоджає його одужанню [6, с. 119].

Співзалежним властиве заперечення патологічної прив'язаності, применшення проблем. Поведінкою часто рухає страх самотності, осуду оточуючих, страх за життя хворого, відсутність власних орієнтирів у житті. Тому такі люди весь час знаходяться поруч, супроводжують на прогулянках, походах до лікаря, вибирають одяг, готують їжу - організовують побут згідно 3 потребами партнера, нехтуючи власним комфортом i бажаннями. У співзалежної людини знижена соціальна відповідальність, всі проблеми пояснюються захворюванням аддикта. Відносини реалізуються з позицій «батько» і «дитина»: один проявляє любов, турботу, прощення, інший дозволяє собі «капризи» - алкоголь, наркотики, неробство, насильство, образи. Співзалежні інтерпретують свою поведінку позитивно, як здатність любити людину з усіма їі недоліками і слабкостями. Такі відносини можуть 
тривати роками, не роблячи учасників щасливими. Тривала співзалежність супроводжується накопиченням негативних емоцій, які відкидаються як неприйнятні. Роздратування, гнів, розчарування, пригніченість i страх придушуються. Зростаюча напруга в результаті проявляється неконтрольованими спалахами ауто- i гетероагрессіi, маскованих депресією [13, с. 301]. Співзалежні знаходяться в групі високого ризику суїцидальної поведінки, часто виявляються соціально дезадаптованими, так як весь свій час і сили витрачають на догляд за хворим. Для залежного ускладненням $\epsilon$ посилення патологічної звички, висока ймовірність рецидиву після курсу лікування.

Таким чином, незважаючи на досягнуті результати в науковому дослідженні феномена залежності, найбільшу актуальність зберігає проблема його вивчення як негативного біопсіхосоціодуховного явища i розробки способів його попередження, здатних не тільки стримати зростання, але i надати ефективну протидію виникненню і подальшому поширенню.

Формулювання мети статті. Мета полягає у вивченні психологічних особливостей особистості в співзалежних стосунках у парі.

Виклад основного матеріалу. Психологічна база досліджування склала 82 осіб (41 пара ). Виходячи зі специфіки дослідження, були відібрані обстежувані з урахуванням особливостей взаємин у їхніх сім'ях. Відповідно до цього, досліджувані склали дві групи вибіркової сукупності: контрольна досліджувана група - 40 осіб (20 подружніх пар) - які характеризувалися стабільними, сприятливими взаєминами адаптовані пари, що не мають подружніх утруднень і задоволені шлюбом; основна досліджувана група - 42 осіб (21 подружні пари ) - які зверталися до психологічної консультації у зв’язку з проблемами співзалежності, незадоволення шлюбом,- це ті пари, які можуть бути віднесені до пізніх, або фінальних, етапів залежності. Досліджувані групи були співставні за рівнем освіти, віком та соціальним походженням. Вік обстежуваних - від 25 до 45 років, 75\% - люди від 30 до 45 років, 25 \% досліджуваних - від 25-30 років. Сімейний стаж подружжя 
становив 5 і більше років і всі вони перебували в першому шлюбі. Всі вони мешкають у Києві.

Для дослідження психоемоційних станів досліджуваних основної та контрольної груп були обрані валідні психодіагностичні методики: Тестопитувальник Спілбергера-Ханіна (діагностика тривожності); Опитувальник тріади любові по Стернбергу; Тест на співзалежність Фішера; Тест «впевненість у собі» Райдаса ; Виявлення любовної залежності (по Сгорову).

Любовна залежність є одним із видів співзалежності, таким же, як залежність від наркотиків, алкоголю, віртуальних ворожінь або ігрових автоматів. Незважаючи на це, багато людей приймають залежність за любов. I вони щиро вважають, що біль - це властивість любові, хоча насправді це властивість залежності. Власне, це одна із головних труднощів у лікуванні любовної залежності: поки свою душевну біль людина сприймає як вияв своєї любові, він позбавляється від неї не хоче.

Для вивчення наявності виявлення любовної співзалежності у подружніх парах провели дослідження цих пар, у порівнянні 3 не співзалежними парами (таб. 1., рис. 1.).

У співзалежних особистостей, які перебувають у стосунках залежної любові, більш виражені схильність до підкорення й до уникнення почуття провини, у них також більш високий рівень тривожності й напруженості, більш високий рівень самокритики й більш низький рівень артистичності.

Висока тривожність, напруженість і схильність до самокритики пов’язані зі схильністю особистостей, які перебувають у стосунках залежної любові, контролювати свої гедоністичні імпульси, стримувати їхній прояв.

Таким чином, особистості, які вступають у стосунки залежної любові, прагнуть перекладати відповідальність на інших; у них зовнішній локус контролю й регуляція власної поведінки здійснюється не за рахунок зрілих механізмів Его, а за рахунок інфантильних механізмів придушення гедоністичних проявів (очевидно, пов’язаних із структурою Супер-Его). 
Низький рівень особистісної тривожності: основна група 2 особи $(4,8 \%)$; контрольна група 9 осіб (22,5\%). Помірний рівень особистісної тривожності: основна група 3 особи (7,2\%); контрольна група 26 осіб $(65,0 \%)$.

Таблиця 1.

\section{Результати дослідження основної та контрольної груп за тестом на}

\section{тривожність Спілбергера-Ханіна}

\begin{tabular}{|c|c|c|c|c|c|}
\hline \multirow{3}{*}{$\begin{array}{c}\text { Показник особистісної } \\
\text { тривожності }\end{array}$} & \multicolumn{4}{|c|}{ Досліджувана група } & \multirow{3}{*}{$\begin{array}{c}\text { t-критерій } \\
\text { Стьюдента } \\
\text { для } \\
\text { непов'язаних } \\
\text { сукупностей } \\
\text { (f=80, } \\
\text { tкрит=1,99 при } \\
\alpha=0,05) \\
\end{array}$} \\
\hline & \multicolumn{2}{|c|}{ Основна } & \multicolumn{2}{|c|}{ Контрольна } & \\
\hline & абс. число & $\%$ & абс. число & $\%$ & \\
\hline $\begin{array}{l}\text { Низький рівень } \\
\text { особистісної тривожності }\end{array}$ & 2 & 4,8 & 9 & 22,5 & 49,50 \\
\hline $\begin{array}{l}\text { Помірний рівень } \\
\text { особистісної тривожності }\end{array}$ & 3 & 7,2 & 26 & 65,0 & 162,63 \\
\hline $\begin{array}{l}\text { Високий рівень } \\
\text { особистісної тривожності }\end{array}$ & 15 & 35,6 & 4 & 10,0 & 77,78 \\
\hline $\begin{array}{l}\text { Занадто високий рівень } \\
\text { тривожності (межовий } \\
\text { стан) }\end{array}$ & 22 & 52,4 & 1 & 2,5 & 148,49 \\
\hline Всього & 42 & 100 & 40 & 100 & \\
\hline
\end{tabular}

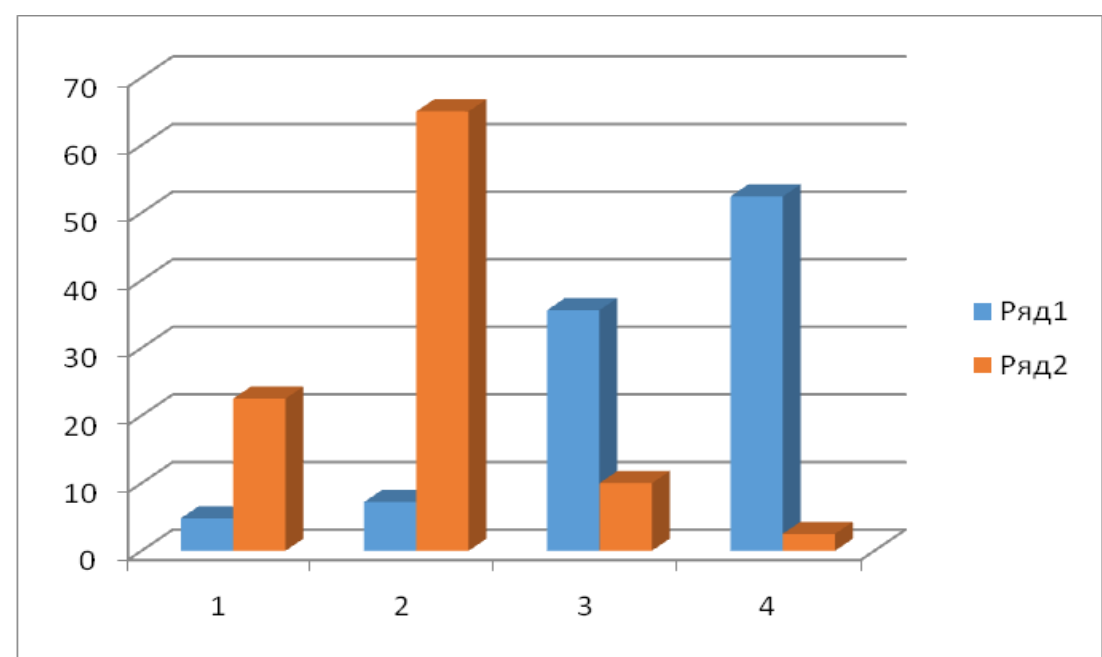

Рис. 1.Порівняння показників тривожності основної (ряд 1) та контрольної (ряд 2) досліджуваних груп за тестом Спілбергера-Ханіна (1- низький, 2помірний, 3 - високий, 3 - занадто високий рівень тривожності) 
Високий рівень особистісної тривожності: основна група 15 осіб (35,6\%); контрольна група 4 особи $(10,0 \%)$. Занадто високий рівень тривожності (межовий стан): основна група 22 особи ( 52,4\%); контрольна група 1 особа $(2,5 \%)$.

Значні відхилення від рівня помірної тривожності вимагають особливої уваги, висока тривожність передбачає схильність до появи стану тривоги у людини в ситуаціях оцінки його компетентності. В цьому випадку слід знизити суб’єктивну значимість ситуації і завдань і перенести акцент на осмислення діяльності та формування почуття впевненості в успіху. Низька тривожність, навпаки, вимагає підвищення почуття відповідальності і уваги до мотивів діяльності. Але іноді дуже низька тривожність активного витіснення особистістю високої тривоги ставить за мету показати себе в «кращому світлі». Співзалежні люди мають труднощі 3 тим, щоб визнати наявність залежності і часто воліють утримувати свої уявлення про те, що таке любов, яка в них дорівнює стражданню.

Нами досліджувалися розходження в структурі любові між особистостями, схильними до стосунків залежної любові, й не схильними до таких стосунків. Використовувався опитувальник тріади любові Стернберга (таб. 2., рис. 2.).

Опитувальник Стернберга показав, що основним компонентом у структурі любові співзалежних особистотей, які перебувають у стосунках залежної любові, $є$ пристрасть і віданність , потім близкість, у порівнянні із групою незалежних особистостей, розмір показників нижчий. По показнику страсті значущих розходжень між групами виявлено не було. Дефіцит близькості в групі жінок, які перебувають у стосунках залежної любові, можна пояснити схильністю таких жінок не бути у зоні реального контакту, заміщаючи його фантазіями та не наповнюючи спілкування емоційністю. Відбувається це через страх перед емоціями, страху покарання за власну емоційність. Оскільки пристрасть сама по собі, будучи більш фізіологічною за своєю природою, не вимагає обов'язкового підключення іiі до емоційної 
сфери, можливий такий сценарій розвитку стосунків, за якого при страху партнерів перед емоційним спілкуванням і інтимною близькістю.

Близкість: основна група 9 осіб (21,4\%); контрольна група 13 осіб (32,5\%). Пристрать: основна група 21 осіб (50,0\%); контрольна група 19 осіб (47,5\%). Віданність: основна група 12 осіб (28,6\%); контрольна група 8 осіб $(20,0 \%)$.

Таблиця 2.

Результати дослідження основної та контрольної груп за тестом « Опитувальник тріади любові за Стернбергом»

\begin{tabular}{|l|c|l|l|l|l|}
\hline \multirow{2}{*}{$\begin{array}{l}\text { Показники одного 3 } \\
\text { компонентів любові }\end{array}$} & \multicolumn{2}{|l|}{ Досліджувана група } & t-критерій \\
\cline { 2 - 6 } & Основна & & \multicolumn{2}{l|}{ Контрольна } & Стьдента \\
\cline { 2 - 6 } & aбс. число & $\%$ & абс. число & $\%$ & $\begin{array}{l}\text { для } \\
\text { неповязаних } \\
\text { сукупнстей } \\
\text { (f=80, } \\
\text { tкрит=1,99 при } \\
\alpha=0,05)\end{array}$ \\
\hline Близкість & 9 & 21,4 & 13 & 32,5 & 28,28 \\
\hline Пристрать & 21 & 50,0 & 19 & 47,5 & 14,14 \\
\hline Віданність & 12 & 28,6 & 8 & 20,0 & 28,28 \\
\hline Всього & 42 & 100 & 40 & 100 & \\
\hline
\end{tabular}

Опитувальник Стернберга показав, що основним компонентом у структурі любові жінок, які перебувають у стосунках залежної любові, $є$ близькість, однак у порівнянні із групою незалежних жінок, розмір цього показника, а також показника відданості, значущо нижче. По показнику пристрасті, значущих розходжень між групами виявлено не було. Дефіцит близькості в групі жінок, які перебувають у стосунках залежної любові, можна пояснити схильністю таких жінок не бути у зоні реального контакту, заміщаючи його фантазіями та не наповнюючи спілкування емоційністю. Відбувається це через страх перед емоціями, інтроецированістю страху покарання за власну емоційність. 


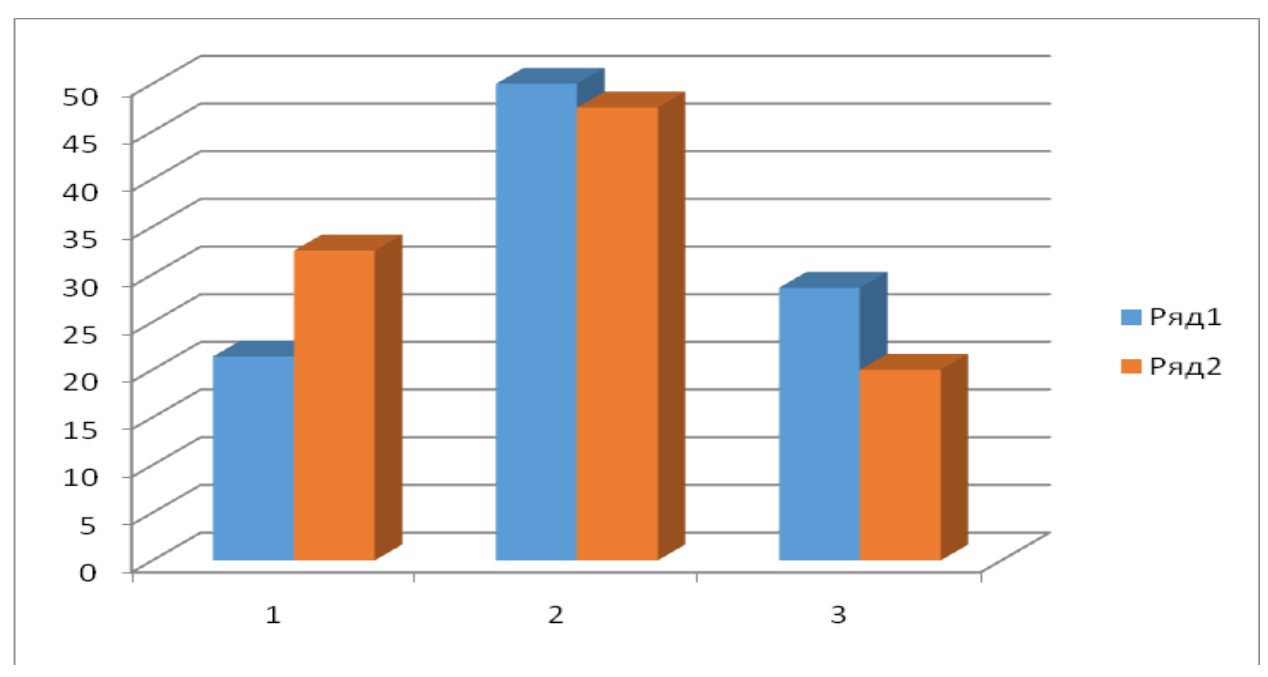

Рис. 2. Порівняння результатів дослідження основної (ряд 1) та контрольної (ряд 2) досліджуваних груп за тестом «Опитувальник тріади любові» за Стернбергом (1-близькість, 2-пристрасть, 3 -відданість)

Оскільки пристрасть сама по собі, будучи більш фізіологічною за своєю природою, не вимагає обов'язкового підключення іiі до емоційної сфери, можливий такий сценарій розвитку стосунків, за якого при страху партнерів перед емоційним спілкуванням і інтимною близькістю, коли б пристрась супроводжувалася близькістю, виникає підкріплювана обома партнерами механічна тенденція задовольняти фізіологічні потреби організму, пов'язані зі статевою сферою. Оскільки інстинкт за своєю природою компульсивен, такі стосунки схильні до нав'язливості. Однак, 3 огляду на той факт, що компонент страсті не є домінуючим, можливий i сценарій, за якого стосунки, не підкріплювані навіть силою інстинкту, силою фізіології, стають порожніми, мало чим наповненими. У цьому випадку перед кожним з партнерів буде поставати питання, що зробити, щоб стосунки тривали, наповнювалися яким-небудь змістом. Найімовірнішим, для жінок, які перебувають у стосунках залежної любові, буде перекладати всю відповідальність за встановлення наповнених близькістю стосунків на партнера. У цьому випадку, можливий відхід партнера із цих стосунків, і постане проблема самітності й непотрібності жінки. 
Щоб визначити особливості формування особистості жінок насамперед, у групі жінок, які перебувають у стосунках залежної любові, значущо переважають наступні негативні фабули:

- Я покинута й нікому не потрібна;

- Я не кохана;

- Я із себе нічого не виявляю;

- Я невродлива;

- Зі мною ніхто не вважається;

- Я зневажувана;

- Я не являю цінність для інших;

- Я не варта любові.

3 тесту Фішера, ми бачимо явну співзалежність до фази Виснаження у основній групі, при тому, що у контрольній групі 72,0\% осіб не залежні (таб. 3., рис. 3.).

Таблиця 3.

Результати дослідження основної та контрольної груп за тестом на співзалежність Фішера

\begin{tabular}{|c|c|c|c|c|c|}
\hline \multirow{3}{*}{$\begin{array}{l}\text { Показник } \\
\text { співзалежності }\end{array}$} & \multicolumn{4}{|c|}{ Досліджувана група } & \multirow{3}{*}{$\begin{array}{l}\text { t-критерій } \\
\text { Стьюдента для } \\
\text { непов'язаних } \\
\text { сукупностей (f=80, } \\
\text { tкрит=1,99 при } \\
\alpha=0,05)\end{array}$} \\
\hline & \multicolumn{2}{|c|}{ Основна } & \multicolumn{2}{|c|}{ Контрольна } & \\
\hline & абс. число & $\%$ & абс. число & $\%$ & \\
\hline $\begin{array}{l}\text { Помірно виражена } \\
\text { співзалежність } \\
\text { (можливо стадія } \\
\text { адаптації) }\end{array}$ & 2 & 4,7 & 29 & 72,5 & 190,92 \\
\hline $\begin{array}{l}\text { Явно виражена } \\
\text { співзалежність }\end{array}$ & 12 & 28,6 & 10 & 25,0 & 14,14 \\
\hline $\begin{array}{l}\text { Небезпечна } \\
\text { співзалежність (фаза } \\
\text { виснаження }\end{array}$ & 28 & 66,7 & 1 & 2,5 & 190,92 \\
\hline Всього & 42 & 100 & 40 & 100 & \\
\hline
\end{tabular}


Помірно виражена співзалежність,- Можливо, ви в стадії Адаптації: основна група 2 особи (4,7\%); контрольна група 29 осіб (72,5\%). Явно виражена співзалежність: основна група 12 осіб (28,6\%); контрольна група 10 осіб (25,0\%). Небезпечна співзалежність,- Фаза Виснаження: основна група 28 осіб (66,7\%); контрольна група 1 особа (2,5\%).

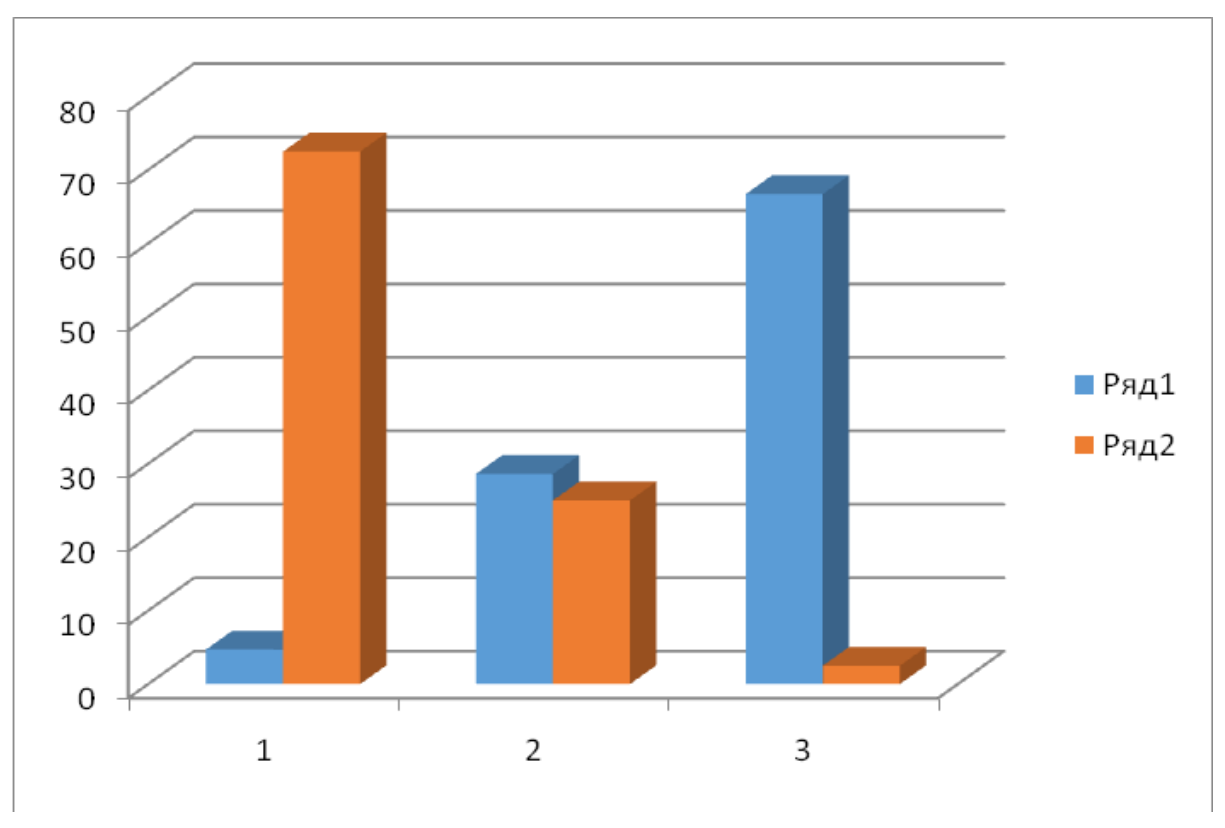

Рис. 3. Порівняння результатів дослідження основної (ряд 1) та контрольної (ряд 2) досліджуваних груп за тестом на співзалежність (1- помірна, 2-явно виражена, 3 - небезпечна співзалежність)

Впевнена в собі людина володіє такими якостями, що проявляються в діяльності, в манері поведінки і мови: цілеспрямованість, наполегливість, готовність ризикувати; усвідомлення себе господарем власної долі, відповідальність за все, що відбувається 3 ним, самостійність у прийнятті рішень; активне і неупереджене сприйняття дійсності, хороша орієнтація в ній; прийняття себе та інших такими, якими вони $\epsilon$; відкритість i доброзичливість у вираженні своїх почуттів i думок; емоційна врівноваженість, делікатність у стосунках з людьми в поєднанні з твердістю по справі; гнучкість поведінки з урахуванням обставин, що змінилися, індивідуальний підхід до людей; стимулювання інших людей шляхом 
підбадьорювання, підтримування, щирого захоплення їхніми успіхами (не дратує, що не принижує інших людей);оперативна i результативна організація колективних обговорень проблем; стимулювання і підтримання сприятливого психологічного клімату в колективі. Та, в свою чергу, це дуже важливо і залишає свій відбиток у співзалежних особистостей.

Для вивчення наявності рівня впевненості у собі у співзалежних особистостей, в порівнянні з не співзалежними особистостями у парах, нами було використано Тест Райдаса (таб. 4., рис. 4.).

Таблиця 4.

\section{Результати дослідження основної та контрольної груп за тестом Райдаса}

«Впевненість у собі»

\begin{tabular}{|c|c|c|c|c|c|}
\hline \multirow{3}{*}{$\begin{array}{l}\text { Показник } \\
\text { впевненості в собі }\end{array}$} & \multicolumn{4}{|c|}{ Досліджувана група } & \multirow{3}{*}{$\begin{array}{l}\mathrm{t} \text {-критерій } \\
\text { Стьюдента для } \\
\text { непов'язаних } \\
\text { сукупностей }(\mathrm{f}=80, \\
\text { tкрит=1,99 при } \alpha=0,05)\end{array}$} \\
\hline & \multicolumn{2}{|c|}{ Основна } & \multicolumn{2}{|c|}{ Контрольна } & \\
\hline & абс. число & $\%$ & $\begin{array}{l}\text { абс. } \\
\text { число }\end{array}$ & $\%$ & \\
\hline $\begin{array}{l}\text { Дуже невпевнений у } \\
\text { собі }\end{array}$ & 33 & 78,6 & 3 & 7,5 & 212,13 \\
\hline $\begin{array}{l}\text { Скоріше не } \\
\text { впевнений, ніж } \\
\text { впевнений }\end{array}$ & 7 & 16,7 & 1 & 2,5 & 42,43 \\
\hline $\begin{array}{l}\text { Середнє значення } \\
\text { впевненості }\end{array}$ & 2 & 4,2 & 15 & 37,5 & 91,92 \\
\hline Впевнений в собі & 0 & 0 & 18 & 45,0 & 127,28 \\
\hline $\begin{array}{l}\text { Занадто } \\
\text { самовпевнений }\end{array}$ & 0 & 0 & 3 & 7,5 & 21,21 \\
\hline Всього & 42 & 100 & 40 & 100 & \\
\hline
\end{tabular}

В даному тесті ми бачимо, що більшість із співзалежних осіб є дуже невпевненими в собі, тобто, невпевненість у собі, в своїх діях, в успішному завершенні будь якої справи тощо, дуже пов'язані зі співзалежною поведінкою.

Дуже невпевнений у собі: $\quad$ основна група 33 особи $\quad(78,6 \%)$; контрольна група 3 особи (7,5\%). Скоріше не впевнений, ніж упевнений: основна група 7 осіб (16,7\%); контрольна група 1 особа (2,5\%). Середнє 
значення впевненості: основна група 2особи (4,2\%); контрольна група 15 осіб (37,5\%). Впевнений у собі: основна група 0 осіб; контрольна група 18 осіб (45,0\%). Занадто самовпевнений: основна група 0 осіб; контрольна група 3 особи $(7,5 \%)$.

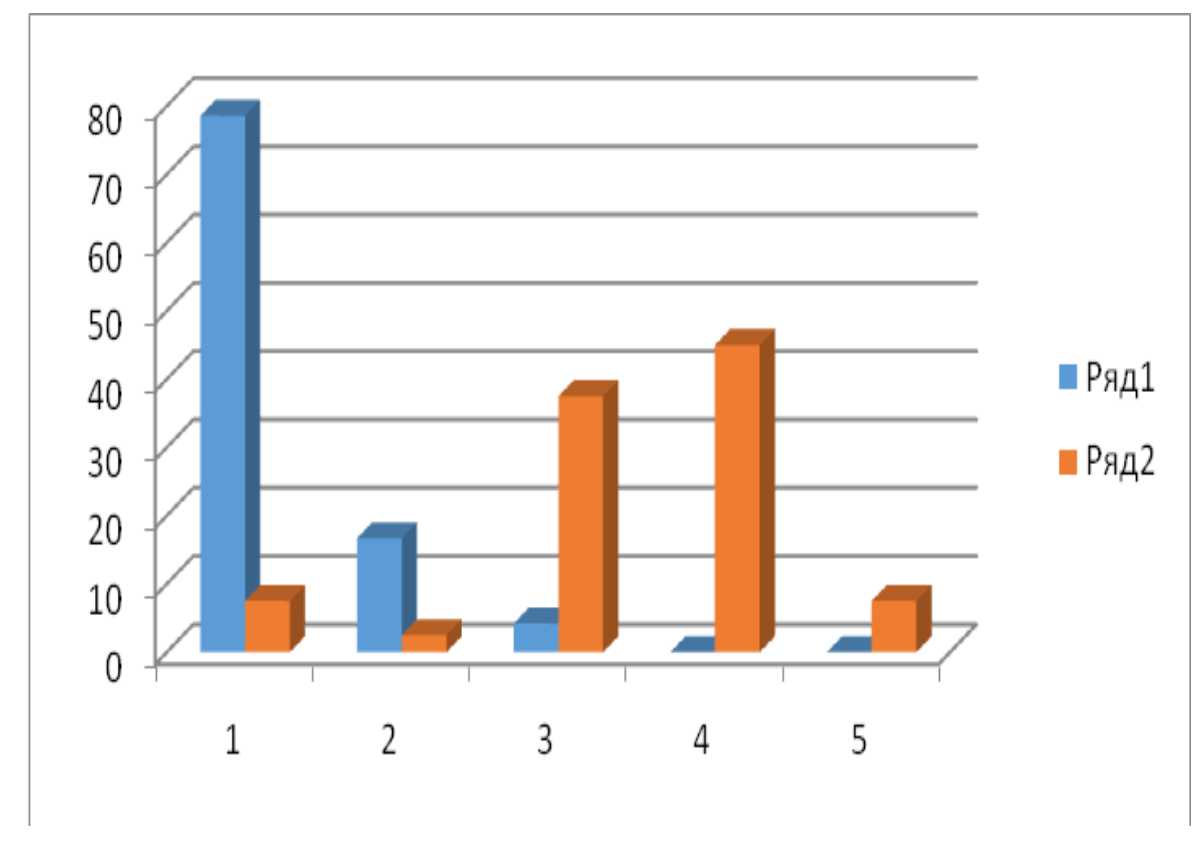

Рис. 4. Порівняння показників упевненості в собі за тестом Райдаса основної (ряд 1) та контрольної (ряд 2) досліджуваних груп (1-дуже невпевнений, 2скоріше впевнений, 3- середнє значення впевненості, 4- впевнений, 5 занадто самовпевнений)

Результати дослідження любовної аддикції за тестом Єгорова представлені в таб. 5. і графічно зображені на рис. 5.

Як видно з данної таблиці, у співзалежних пар дуже високий рівень любовної аддикції, тоді як у не співзалежних пар вона дуже знижена. Висока вірогідність любовної аддикції (згода 311 та більше ) основна група 39 осіб (92,9\%); контрольна група 7 осіб (17,5\%).

Можлива любовна аддикція (згода 3 5-10 твердженнями) основна група 1 особа (2,4\%); контрольна група 13 осіб (32,5\%).

Любовна аддикція не виявлена (згода менше ніж із 5 твердженнями) основна група 2 особи (4,7\%); контрольна група 20 осіб (50,0\%). 
Таблиця 5.

\section{Результати дослідження основної та контрольної груп за тестом виявлення любовної аддикції (за Сгоровим).}

\begin{tabular}{|c|c|c|c|c|c|}
\hline \multirow{3}{*}{$\begin{array}{l}\text { Показник любовної } \\
\text { аддикції (залежності) }\end{array}$} & \multicolumn{4}{|c|}{ Досліджувана группа } & \multirow{3}{*}{\begin{tabular}{|l} 
t-критерій \\
Стьюдента для \\
непов'язаних \\
сукупностей \\
(f=80, \\
tкрит $=1,99$ при \\
$\alpha=0,05)$
\end{tabular}} \\
\hline & \multicolumn{2}{|c|}{ Основна } & \multicolumn{2}{|c|}{ Контрольна } & \\
\hline & $\begin{array}{l}\text { абс. } \\
\text { Число }\end{array}$ & $\%$ & абс. число & $\%$ & \\
\hline $\begin{array}{l}\text { Висока вірогідність } \\
\text { любовної аддикції } \\
\text { (згода з } 11 \text { та більше } \\
\text { твердженнями) }\end{array}$ & 39 & 92,9 & 7 & 17,5 & 226,27 \\
\hline $\begin{array}{l}\text { Можлива любовна } \\
\text { аддикція (згода } 35-10 \\
\text { твердженнями) }\end{array}$ & 1 & 2,4 & 13 & 32,5 & 84,85 \\
\hline $\begin{array}{l}\text { Любовна аддикція не } \\
\text { виявлена (згода } \\
\text { менше ніж із } 5 \\
\text { твердженнями) }\end{array}$ & 2 & 4,7 & 20 & 50,0 & 127,28 \\
\hline Всього & 42 & 100 & 40 & 100 & \\
\hline
\end{tabular}

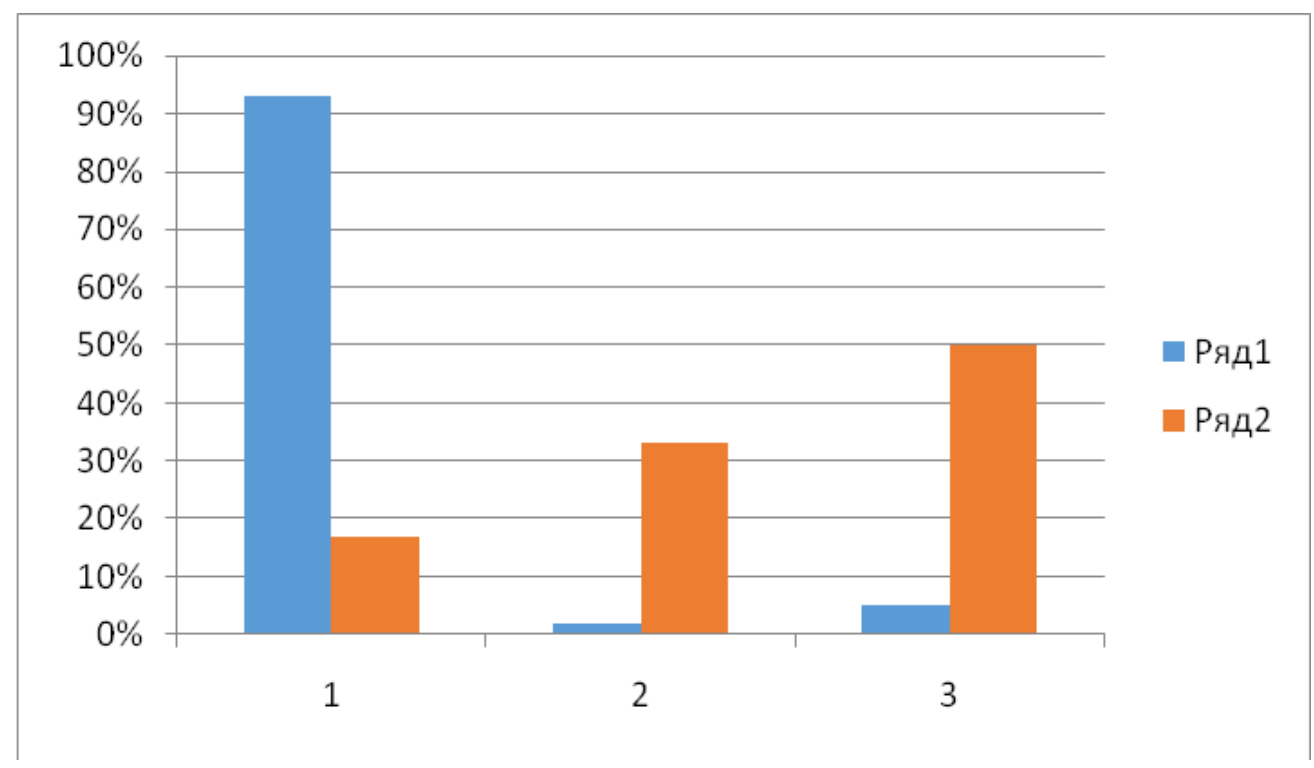

Рис. 5. Співвідношення показників любовної аддикції (за Сгоровим) в основній (ряд 1) і контрольній (ряд 2) досліджуваних групах (1- високий показник аддикції, 2 - аддикція можлива, 3 - аддикція не виявлена) 
Висновки та перспективи подальших досліджень. В проведеному дослідженні були виявлені стратегії міжособистісної взаємодії жінок і чоловіків з співзалежною поведінкою. Особи з високим рівнем співзалежної моделі поведінки відчувають психічну напругу від невпевненості в собі, зневіри у власні сили, залежність від людей, відчуття перебування в пастці принижуючих, контролюючих взаємин. Для того, щоб відчути, що в них все добре, їм необхідно постійно задовольняти потребу в схваленні, реалізовувати очікування підтримки. Вони переживають безсилля щодо змін тих особливостей спілкування 3 партнером, які їм не подобаються. Для зняття або послаблення психічної напруги, відволікання від переживань, що пригнічують вони схильні звертатися до зовнішніх стимуляторів, зазнають труднощів вибудовування власного психологічного простору, його меж.

Більшість жінок та чоловіків, які взяли участь у нашому дослідженні, не намагаються приховувати звичайні страхи, занепокоєння або свою невпевненість. Вони намагаються добре виглядати в своїх очах та в очах партнерів, не завжди потребують бути «правими», відчувають нестачу довіри 3 боку близької людини i занепокоєння при встановленні близьких, довірливих відносин.

Результати наших досліджень підтверджують дані джерел наукової літератури, що співзалежним людям властиво: заперечення, страх, тривога, сором, вина, перфекціонізм, нав'язливі думки, невміння дотримуватися кордону особистості, схильність до маніпулювання, ригідність.

Дослідження проблеми співзалежності є значущими для психологів, тому що дане питання потребує більш грунтовного теоретичного вивчення.

\section{Список використаних джерел}

1. Бейдер Е.: В пошуках міфічної пари: навч. посібник / Бейдер Е., Пірсон П. [пер. з англ. і ред. Н. А. Цвєткова]: Вид. 2-ге стереотипне. - М.: НОУ ВПО Вид-во Московського психолого-соціального ін-ту, 2008. - 302 с. 
2. Коцар А. В. Особливості психосексуального розвитку хворих на невроз жінок, що знаходяться у відносинах подружньої залежності: Автореф. канд.. психол. наук / А. В. Коцар. - К., 2002.- 19 с.

3. Кочарян А. С. Емоційна структура синдрому«емоційного холоду» / Кочарян А. С. Терещенко Н. Н.Асланян Т. С. - Матеріали науковопрактичної конференції «Психотерапія, медична психологія і гранична психіатрія в системі надання медичної допомоги» (XI Платонівські читання) Харків, 17-18 квітня, 2008. - Харків, 2008.- С.73-74.

4. Кочарян А. С. Синдроми невротичної любові / Кочарян А.С., Коцарь А. В. // Вісник Харківського університету. Серія психологія. - 2000. - № 498. C. $68-72$.

5. Мак-Вільямс Н. Психоаналітична діагностика: Розуміння структури особистості в клінічному процесі / Мак-Вільямс Н. [пер. 3 англ.].М.:Незалежна фірма «Клас», 1998. - 480 с.

6. Медична психологія: навч. посіб. / Н. Г. Пшук, М. В. Маркова, А. І. Кондратюк, Л. В. Стукан. - Вінниця, 2010. - 135 с.

7. Менделевич В. Д. Розлади залежної поведінки (до постановки проблеми) / В. Д. Менделевич // Рос. психіатричний журнал. - 2003. - №1. C.5-9.

8. Москаленко В. Д. Созалежність: характеристики та практика подолання / В. Д. Москаленко // Лекції з наркології; під ред. М. М. Іванця. М.: Нолідж, 2000. - С. 365-405.

9. Мусієнко Г. О. Вивчення механізмів успадкування схильності до залежних станів від тютюну та алкоголю і механізмів їі реалізації під впливом зовнішнього середовища / Г. О. Мусієнко, В. В. Шалашев // Український вісник психоневрології.- 2012. - Т. 20, № 3 (72). - С. 252.

10. Поттер-Ефран Р. Сором, провина та алкоголізм: клінічна практика / Поттер-Ефран Р.- М.: Ін-тзагальногуманітарних досл., 2002.- 416 с.

11. Психологічний словник [ред. В. П. Зінченко, Б. Г. Мещеряков]. - М. : ACT, $2007-480 \mathrm{c}$. 
12. Циганков Б. Д. Протікання хронічного алкоголізму в поєднанні 3 посттравматичним стресовим розладом в залежності від характеру психогенії / Б. Д. Циганков, П. А. Яковлєва, А. С. Коніщев, Т. А. Волгіна // Наркологія.2011.-T.10.- C. 56-59.

13. Шапіро Д. Невротичні стилі / Д. Шапіро.- М.: Ін-т загальногуманітарних досл., 1998. - 197 с.

14. Шутценбергер А. А. Синдром предків / Шутценбергер А. А.- М.: Видво Ін-ту психотерапії, 2005.- 243 с.

\section{References}

1. Beider, E. Pirson, P. (2008), V poshukakh mifichnoi pary: navch. posibnyk [In search of a mythical pair: teach. Manual] [trans. from english and ed. N. A. Tsvetkova], 2nd edl. , LEU HPE Kind of Moscow Psycho-socialIn-th, Moscow, $\mathrm{Ru}$.

2. Kotsar, A. V. (2002), Osoblyvosti psykhoseksual'noho rozvytku khvorykh na nevroz zhinok, scho znakhodiat'sia u vidnosynakh podruzhn'oi zalezhnosti: Avtoref. kand. psykhol. nauk [Features of psychosexual development of patients with neurosis of women who are in the relationship of marital dependence: Author's abstract. Candidate of Psychology. Sciences], Kyiv. Ua.

3. Kocharyan, A. S. Tereshchenko, N. N. and Aslanyan, T. S. (2998), "Emotional Structure of the "Emotional Cold" Syndrome", Materialy naukovopraktychnoi konferentsii «Psykhoterapiia, medychna psykholohiia i hranychna psykhiatriia $v$ systemi nadannia medychnoi dopomohy» (KhI Platonivs'ki chytannia) Kharkiv, 17-18 kvitnia, 2008, Kharkiv, Ua.

4. Kocharyan, A. S. Kotsar, A. V. (2000), Syndromes of Neurotic Love, Visnyk Kharkivs'koho universytetu. Seriia psykholohiia, vol. 498, pp. 68 - 72.

5. McVilliams, N. (1998), Psykhoanalitychna diahnostyka: Rozuminnia struktury osobystosti $v$ klinichnomu protsesi, [Psychoanalytic Diagnosis: Understanding the Personality Structure in the Clinical Process], [trans. from Eng.], Independent firm "Klass”, Moscow, Ru. 
6. Medychna psykholohiia: navch. posib. [Medical Psychology: Teach. manual], Pshuk, N. G. Markov, M. V. Kondratyuk, A. I. And Stucan, L. V. (2010), Vinnitsa, Ua.

7. Mendelevich, V. D. (2000), "Disorders of Dependent Behavior (to the Problem Statement)", Ros. psykhiatrychnyj zhurnal, vol. 1, pp. 5-9.

8. Moskalenko, V. D. (2000), "Co-dependence: characteristics and practice of overcoming", Lektsii z narkolohii; pid red. M. M. Ivantsi [ed. M. M. Ivan'ets], Noelig, Moscow, Ua, pp. 365-405.

9. Musienko, G. O. Shalashev, V. V. (2012), "Study of mechanisms of inheritance of predisposition to dependent states from tobacco and alcohol and mechanisms for its implementation under the influence of the external environment", Ukrains'kyj visnyk psykhonevrolohii, vol. 20, No. 3 (72), pp. 252.

10. Potter-Efran, R. (2002), Sorom, provyna ta alkoholizm: klinichna praktyka, [Shame, Guilt and Alcoholism: Clinical Practice], In-Humanitarian Literature, Moscow, Ru.

11. Psykholohichnyj slovnyk, Psychological Dictionary [ed. V.P. Zinchenko, B.G. Meshcheryakov] (2007), AST, Moscow, Ru.

12. Tsigankov, B. D. Yakovlev, P. A. Konishchev, A. S. and Volgin T. A. (2011), "The occurrence of chronic alcoholism in combination with post-traumatic stress disorder, depending on the nature of psychogeny", / B. D. Tsigankov, // Narkolohiia, vol. 10, pp. 56-59.

13. Shapiro, D. (1998), Nevrotychni styli, [Neurotic styles], Institute of Humanities, Moscow, Ru.

14. Schutzenberger, A. A. (2005), Syndrom predkiv, [Syndrome of ancestors], Vyd-vo In-tu psykhoterapii, Voscow, Ru. 